\title{
Prag Uluslararası Öğretmenler Kongresi
}

\section{Prague International Teachers Congress}

\begin{tabular}{|c|c|}
\hline & Sabri BECERIKKLI ${ }^{1}$, Zafer TANC \\
\hline $\begin{array}{l}\text { Anahtar Kelimeler } \\
\text { Prag Uluslararası } \\
\text { Öğretmenler Kongresi, } \\
\text { Ali Haydar (Taner), } \\
\text { Öğretmen, } \\
\text { Eğitim. }\end{array}$ & 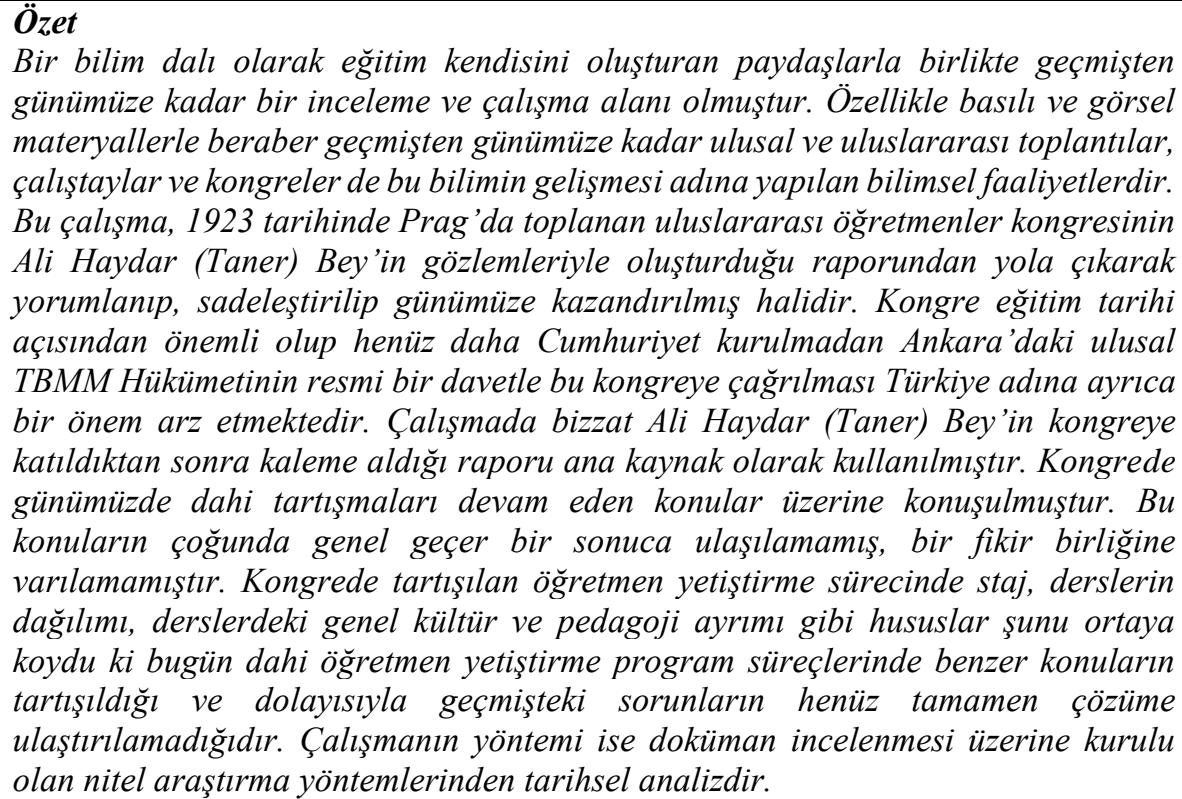 \\
\hline
\end{tabular}

\section{Abstract}

Education, as a branch of science, has been a field of study and investigation from past to present together with the stakeholders that constitute the education itself. The national and international meetings, workshops and congresses that have continued from past to present, especially with printed and visual materials, are the scientific activities carried out for the development of this particular field of science. The present study is the interpreted, simplified version that has been brought to the present time, based on the report created by Mr. Ali Haydar (Taner)'s observations of the international teachers congress that was held in Prague in 1923. The congress was important for the history of education; it was vitally significant for Turkey for the national Parliamentary Government in Ankara to be summoned to this congress via an official invitation even before the Republic was founded. In this study, the very

$\underline{\text { Key Word }}$

Prague International Teachers Congress, Mr.Ali Haydar (Taner), Teacher, Education. report that Mr. Ali Haydar (Taner) wrote himself after attending the congress was used as the main source of examination. At this congress, the issues that have still been contentious even today were discussed. Regarding most of these issues, no valid general conclusion could be reached and no consensus could be arrived at. The issues such as internship, distribution of courses, the distinction between general culture and pedagogy in the teacher training process discussed in the congress revealed that similar issues have still been under discussion even today in the processes of teacher training programs and therefore, problems of the past have not yet been fully resolved. The method of this particular study is the historical analysis based on document analysis, which is one of the qualitative research methods.

\begin{tabular}{|c|c|}
\hline $\begin{array}{l}\text { Atıf için: } \\
\text { For Citation }\end{array}$ & $\begin{array}{l}\text { Becerikli, S., \& Tangülü, Z. (2019). Prag uluslararas1 öğretmenler kongresi. Muğla Sitkl } \\
\text { Koçman Üniversitesi Eğitim fakültesi [MSKU Journal of Education], 7(2), 111-121. DOI: } \\
\text { [0.21666/muefd.750080 }\end{array}$ \\
\hline Rece & Published: 01.11.2020 \\
\hline
\end{tabular}

\footnotetext{
${ }^{1}$ Bursa Uludağ Üniversitesi EF, beceriklisabri@uludag.edu.tr, ORCID: 0000-0003-3307-6979

${ }^{2}$ Muğla Sıtkı Koçman Üniversitesi EF, zafertangulu@ gmail.com, ORCID: 0000-0003-1596- 442x
} 
Öğretim işinin ve bir meslek olarak öğretmenliğin tam olarak nerede ve ne zaman ortaya çıktığı kesin olarak bilinmese de gerek gündelik gerekse pedagojik olarak insanoğlu hep bir şeyi öğrenme ve öğrendikten sonra da bilgisini paylaşma gayreti içinde olmuştur. Bu yüzden öğrenme ve öğretme çabası aslında insanlık tarihi kadar eskidir.

Mısır, Çin, Hint ve Yunan gibi eski uygarlıklarda okulların olduğu ve bu okullarda öğretim gerçekleştirildiği bilinmektedir. Eski çağın en dikkat çekici öğretmenleri ise filozoflarıdır. Yunan şehir devletlerinde ücret karşıllğında ders vermiş olan sofistleri öğretmenlik mesleğinin antik çağlardaki en bariz örnekleri olarak nitelendirmek mümkündür. Sofistler, özel dersler vermişler, kendi açtıkları okullara zengin ailelerin çocuklarını yönlendirerek öğretmenlik mesleğinden gelir elde etmişlerdir. Roma döneminde öğretmenlerin itibarı yükselmiş ve öğretmenler mesleklerinden kaynaklı olarak ciddi derecede gelirler elde etmişlerdir. Hristiyanlığın doğuşu ve yaygınlık kazanması ile birlikte ortaçağ Avrupa'sında eğitim ve öğretimin temeli dine dayandırılmıştır. Avrupa'da önemli katedral ve manastırlarda dünyevi bilimler de öğretilmesine rağmen okullardaki öğretmenlik işini din görevlileri gerçekleştirmiştir. İslam dünyasındaki eğitim, din ağırlıklı olması açısından Hristiyan dünyası ile benzerlik göstermiştir. Fakat Müslümanlar medrese denilen müstakil okulları açarak eğitim-öğretim faaliyetlerini daha müspet yürütmüşlerdir. Rönesans ve Reform hareketleri Avrupa'nın düşünce dünyasını evrimleştirmiştir. Bu dönemlerde ortaya çıkan düşünceler din temelli yapıya karşı gelmiştir. Böylece eğitimin üzerindeki kilise baskısı da kırılmaya başlanmıştır. Aydınlanma çağını yaşamış olan Batı'da kiliseyi eğitim kurumlarından uzaklaştırmak amacıyla devlet okulları açma girişimi başlatılmış, eğitim-öğretimde seküler anlayış ortaya çıkmış ve bu durum öğretmen eğitimine de yansımıştır (Becerikli, 2019a).

Dünyada öğretmenliğin profesyonel olarak bir meslek kolu haline gelmesi ve mesleğe ilişkin süreçlerin bugünkü anlamda bilimsel olarak ele alınması Avrupa'da meydana gelen bir dizi siyasi ve sosyal olayların etkisiyle olmuştur. Özellikle Fransız İhtilâli ve Sanayi Devrimi'nden sonra kıta Avrupa'sında ortaya çıkan bir takım değişim ve gelişmeler sonuçları itibariyle uluslararası düzeyde yayılım göstermiştir. Bu süreçlerde öğretmenlik meslek olarak daha fazla gelişim göstermiş, eğitim ve öğretmenlik mesleği ile ilgili paydaşlar, sorunlar ve süreçler daha fazla üzerinde düşünülmesi ve çalışılıp geliştirilmesi gereken bir durum halini almıştır. Bunun sonucu olarak öğretmenlik mesleğine ilişkin bilimsel toplantılar ve seminerler başta Avrupa olmak üzere çeşitli yerlerde yayılım göstermiş, bu toplantılarda alınan kararlar çerçevesinde meslek ve eğitim üzerinde düzenlemelere gidilmiş hatta öğretmen eğitimi geliştirilmeye çalışılmıştır.

1738 'de Almanya'da öğretmenlerin kalitesini artırmak için seminerler düzenlenmeye başlanmıştır. Bu seminerler, Fransa'da da düzenlenmiştir. Seminerleri vermek için çeşitli enstitüler kurulmuş, hatta öğretmen okulları kurulduktan sonra bile seminerler devam etmiştir. Modern anlamda öğretmen okulu ilk olarak 1778 yılında Prusya'da açılmıştır. Fransa'da ise Osmanlı ve Cumhuriyet dönemi için önemli bir kurum olan Yüksek Öğretmen Okulunun model alındığı öğretmen okulunun ilk adımları atılmıştır. 1794 yılında açılmış olan öğretmen okulu 'Ecole Normale' 1795'de eğitim-öğretim faaliyetlerine başlamıştır. Okulun açılmasındaki amaç Fransız devrimlerine sahip çıkacak ve öğretme sanatını öğrenecek öğretmenleri yetiştirmek olarak belirlenmiştir (Becerikli, 2019a).

Klasik döneminde medreselerde öğretmen yetiştiren Osmanlı'da dünyadaki gelişmelerden uzak kalmamış 1848 'de Darülmuallimin adıyla modern anlayışta öğretmen yetiştiren müstakil bir öğretmen okulu açılmıştır. Bu okulun çeşitli kademelere öğretmen yetiştiren şubeleri de açılmış hatta Osmanlı coğrafyasında yaygınlaştırılmıştır. Öğretmenlik mesleği zaman içerisinde ciddi gelişim göstermiş, günümüz anlayışına adım adım gelişerek yaklaşmışıtır (Becerikli, 2019a). Hatta Osmanlı eğitimcileri eğitim üzerine çeşitli çalışmalar yaparak kitap ve makaleler yayımlamışlardır (Şanal, 2002; Oruç \& Kırpık, 2006). Çalışmaya konu olan Prag Uluslararası Öğretmenler Kongresi öğretmen ve eğitim sorunlarının tartışıldığı uluslararası öneme sahip bir organizasyondur. Kongreye ayrıca TBMM Hükümeti'nin davetli olması ve davete icabet edilmesi Türkiye'de eğitim ve öğretmenlik mesleğine verilen değeri ortaya koyma ve savaştan yeni çıkmış bir ülkenin dünyadaki bu tip organizasyonlara kayıtsız kalmaması açısından dikkate değer bir bilimsel toplantıdır. 


\section{Yöntem}

Çalışmanın amacı, bağımsızlık mücadelesinden sonra yeni bir devlet kurmaya çalışan TBMM Hükümetinin böyle bir süreçte bile eğitime verdiği önemin bir örneği olarak karşımıza çıkan Prag uluslararası öğretmenler kongresinde tartışılan konuları ele almaktır. Çalışma 1923 tarihinde Prag'da toplanan uluslararası öğretmenler kongresindeki izlenimlerini kaleme alan Ali Haydar (Taner) Bey'in gözlemleriyle oluşturduğu raporundan oluşturulmuştur. Ayrıca Türkiye Cumhuriyeti Cumhurbaşkanlığı Devlet Arşivleri Başkanlı̆̆ 1 Cumhuriyet Arşivi'nden elde edilen belgeler kullanılmıştır. Bunların dışında çalışmayı zenginleştirmek için çeşitli telif eserlerden yararlanılmıştır. Çalışma da nitel araştırma yöntemlerinden tarihsel analiz kullanılmıştır. "Tarihsel araştırma, geçmişte meydana gelmiş eylemleri ve olayları tanımlamak, açılamak ve böylelikle anlayabilmek için verilerin sistemli olarak toplanması ve değerlendirilmesidir" (Fraenkel, Wallen \& Hyun, 2011, s. 535). Tarihsel araştırmalar genellikle yazılı dokümanlar üzerinden yürütüldüğünden konu ile alakalı arşiv belgeleri, Ali Haydar Bey'in raporu değerlendirilmiş; kongrede tartışılan staj, derslerin dağılımı, derslerdeki genel kültür ve pedagoji ayrımı gibi konular ortaya konulmuştur.

\section{Bulgular}

\section{Prag Uluslararası Öğretmenler Kongresi}

27 Ağustos 1923 ve 30 Ağustos 1923 tarihleri arasında Prag'da bir ortaöğretim ${ }^{3}$ öğretmenleri uluslararası kongresi düzenlenmiştir (Ali Haydar, 1925). Bu kongreyi "Beynelmilel Mekatib-i Taliye Muallimleri Heyeti" düzenlemiştir. Ali Haydar heyetin Fransızca ismini "Bureau ${ }^{4}$ International des Federations Nationale du Personnel de I'enseignement Secondaire Public" şeklinde vermiştir. Belçika öğretmenlerinin oluşturdukları topluluk tarafından bir uluslararası öğretmenler heyeti kurma fikri ileri sürülmüş ve Belçika öğretmenler topluluğunun çağrısı sonucunda diğer ülkelerin öğretmenler toplulukları üyelerinin bazılarının temsili ile birlikte bu "Büro" kurulmuş oldu. Kuruluş aşamasında Fransa'dan Fedel ile Beltette, Hollanda'dan Warenhorst, Belçika adına Wittmann ile Van Lede isimlerindeki kişilerce kendi ülkelerinin öğretmenler toplulukları temsil edilmiştir. "Büro" diğer ülkelerdeki öğretmen topluluklarının üye olarak bünyesine katılımı ile teşkilatlandırılmış bir uluslararası örgüt olarak kurulmuştur. 1912'de ilk toplantı gerçekleştirilmiş ve üye olacaklardan belirli bir yıllık ücret alınması, her topluluğun iki üye ile temsil edilmesi fakat bir oyunun olması kararları alınmıştır. Ayrıca "Büro" kendini eğitim meseleleri ile ilgili bir danışma organı gibi görmüştür. 1913 'de Gent şehrinde bir toplantı gerçekleştirilmiştir. I. Dünya Savaşı'nın ortaya çıkması ile birlikte uluslararası bütün faaliyetler tatil edilmiştir. 1920'de Strazburg'da "Büro"yu yeniden faaliyete geçirmek için Büyük Britanya, Lüksemburg, Cenevre, Çekoslovakya, Belçika, Fransa, Alsas-Loren ögretmenleri toplulukları adına temsilcilerin de katıldığı bir toplantı gerçekleştirilmiştir. Daha sonra ise Paris ve Lüksemburg'da toplantı yapılmış ve 1923'de Prag'da toplanılmıştır. Gent, Strasburg, Lüksemburg ve Paris'teki kongrelere Türkiye'den herhangi bir heyet katılmamıştır (Ali Haydar, 1925).

Ağustos 1923'de Prag'da düzenlenen kongreye Cumhuriyet'in ilanı gerçekleşmediği için TBMM Hükümeti adına gönderilen temsilciler katılmışlardır (BCA, FK.HR.IM.-YN.77.37.1; Ali Haydar, 1925). İstanbul'daki Çekoslovakya temsilciliğinden gelen davet üzerine kongreye Türkiye'den gitmek üzere iki temsilci gönderilmesi düşünülmüştür. İlk temsilci olarak Maarif Müfettişlerinden Zeki Mesud Bey seçilmiştir. İkinci kişinin belirlenebilmesi için İstanbul Muallimler Cemiyetinden tavsiye alınmak için Cemiyete bir yazı gönderilmiştir (BCA, FK.30.18.1.1.-YN.7.16.15; FK.HR.IM.-YN.77.37.1.). Cemiyetin cevabı ile ilgili bir bilgiye rastlanılmasa bile gönderilecek ikinci kişini Darülfünun hocalarından Ali Haydar olduğu tespit edilmiştir. Hatta Ali Haydar'a kongreye katılımı için 400 lira avans verilmiştir. Bunun dışında Ali Haydar'ın gidiş gelişinin 7 gün sürmesi ve orada 18 gün kalması dolayısıyla kendisinin beyanına göre yapmış olduğu masrafları hariç, günlük 10 liradan 25 güne karşılık 250 liralık bir harcırahın, Ali Haydar'a verilmesi kararlaştırılmıştır (BCA, FK.30.18.1.1.YN.9.25.20.). Ali Haydar'ın kongre bitişinden sonra da şehirde kalması, bulunduğu yerin eğitim

\footnotetext{
${ }^{3}$ Tartışmalar bazen lise birinci (ortaokul) devre, bazen de ikinci devre etrafında gerçekleşmiştir. Bu nedenle kongre ortaöğretim diye adlandırılmıştır.

${ }^{4}$ Ali Haydar kongre ile ilgili yazmış olduğu kitabında bazen heyet bazen de "Büro Enternasyonal" tabirini kullanmıştır. Bu çalışmada kuruluşun Fransızca ismine ithafen "Büro” tabiri kullanılmıştır (Ali Haydar, 1925).
} 
kurumlarını ve eğitim-öğretim faaliyetlerini incelemesi, bu süre zarfındaki çalışmaları için kendisine harcırah verilmesi, kayıtlarda tespit edilemese bile onun sadece kongreye katılması için değil aynı zamanda Prag'daki eğitim-öğretimi incelemesi için de bir görev verildiğini düşündürmüştür. Ali Haydar'ın yazdıklarından anlaşıldığı kadarıyla toplantıya Türkiye'den başka Bulgaristan, Çekoslovakya, Fransa, İngiltere, İspanya, İsveç, İtalya, Lehistan, Lüksemburg, Norveç, Ukrayna Mültecileri Temsilcisi, Yugoslavya temsilcileri de katılmıştır (Ali Haydar, 1925).

Türk heyeti temsilcilerinden Ali Haydar Bey kongre ile ilgili izlenimlerini kaleme almış ve kongrede tartışılan konuları not ederek Türkiye'ye geldiğinde yayımlatmıştır. Ali Haydar'ın yazıları, ilk olarak $13,14,25$ ve 26. sayılarında olmak üzere Muallimler Mecmuasının dört sayısında yayımlamıştır. Bundan başka Ali Haydar bir de kongre kitabı çıkarmıştır. Kongre kitabının içeriği Muallimler Mecmuasının 25 ve 26. sayılarında yayımlanan kısımların kitaplaştırılmış halidir (Ali Haydar, 1923a; 1923b; 1924a; 1924b; 1925). Ali Haydar Muallimler Mecmuasının 13 ve 14. sayılarında da Çekoslovakya İntibaları başlıklı makale yazmıştır. Bu yazılarda, Çekoslovakya Cumhuriyeti, Çekoslovakya Muallimler Cemiyeti, Çekoslovakya'da öğretmenlik ile ilgili kanunların içeriğine, öğretmenlerin maaşlarına, kadro unvanlarına, öğretmenlerin nasıl yetiştirildiğine değinmiştir (Ali Haydar, 1923a; 1923b).

\section{Kongrenin Gündemi}

Kongrenin tartışacağ1 konular üç ana başlıkta incelenmiştir. Bunlar; ortaöğretim öğretmenlerinin eğitimleri, ahlak eğitimi ve okul ile aile arasındaki ilişkiler olarak belirlenmiştir. Bu konuların dışında kongrenin asıl konuları içerisinde yer almasa da Lüksemburg kongresinde tartışılmış olan bazı konuların detaylandırılmadan kısaca görüşülmesi uygun bulunmuştur. Bunlar ise; ortaöğretimin 1slahat1, kızların eğitimi, ortaöğretim öğretmenlerinin maddi durumları, ortaöğretimin sonundaki sınavlar ve diplomalar, uluslararası öğrenci değişimi ve bilgi paylaşımı, diplomaların denklikleri, uluslararası kanunlar olmuştur. Fakat Ali Haydar eserinde bazı konuların tartışılmasının uzun sürmediği, üzerine durulmadan geçildiğine dair zaman zaman notlar düşmüştür. Özellikle eserin önemli kısmını kaplayan belirli konular olmuştur. Bu kısımlar eserin içeriğinin verildiği başlık da değerlendirilmiştir. Ayrıca kongrenin dört günlük programı da aşağıda verilen tablodaki gibi planlanmıştır (Ali Haydar, 1925).

Tablo 1

Kongrenin Dört Günlük Programı

\begin{tabular}{|c|c|}
\hline Pazartesi (27 Ăgustos 1923) & Saat \\
\hline Belediye dairesinde toplant1 & 09:00 \\
\hline Tedrisat-1 taliye sergisini ziyaret & $15: 00$ \\
\hline Milli tiyatroda oyun seyredilmesi & 19:00 \\
\hline Salı (28 Ăgustos 1923) & Saat \\
\hline Belediye dairesinde kongrenin açıllışı & 09:00 \\
\hline Şehremanetinde kabul & $11: 00$ \\
\hline Kongrenin mesaisi & 15:00 \\
\hline Ziyafet & $20: 00$ \\
\hline Çarşamba (29 Ağustos 1923) & Saat \\
\hline Kongre mesaisi & 09:00 \\
\hline Prag şehrini ziyaret & $15: 00$ \\
\hline Ziyafet & $20: 00$ \\
\hline Perşembe (30 Ağustos 1923) & Saat \\
\hline Kongre mesaisi & 09:00 \\
\hline Kongrenin son celsesi & $15: 00$ \\
\hline
\end{tabular}

Kongrenin dört günlük programının ilk gününde yapılan toplantıda katılımcıların tanışması gerçekleşmiş ve katılımcılara kongrenin programı verilmiştir. İlk yapılan toplantıdan sonra sergi ve tiyatro ziyareti yapılmıştır. İkinci günde açılış gerçekleşmiş, planlandığı gibi tam dokuzda değil de saat ona doğru aç1lış merasimi başlatılmıştır. Açılış merasimine Çekoslovakya üst düzey bürokratlarıyla katılmıştır. Kongreyi Çekoslovakya muallimler cemiyeti başkanı mösyö Dr. Zakavec Fransızca nutkuyla açmıştır. Zakavec'den sonra Çekoslovakya eğitim bakanı konuşma yapmış ve ondan sonra da Çekoslovakya Cumhurbaşkanının göndermiş olduğu mektup okunmuştur. Çekoslovak yetkililerin konuşmaları bitince kongreye katılan ülkelerin temsilcileri, ülke isimlerinin alfabetik 
sırasına göre konuşma yapmıştır. Yapılan konuşmalarda standart teşekkür ve tebrikler ayrı tutulursa genel olarak dünya savaşının etkisini ve ülkelerin durumunu görmek mümkündür. Ayrıca konuşmaların bazıları birazda siyasi içerikli olmuştur. Kongrenin dili ise Fransızcadır (Ali Haydar, 1925).

Türkiye heyeti, kongrede bir konuşma yapılacağı bilgisine önceden sahip olmadığından diğer ülkelerin temsilcileri konuşmaya başladığında " $\mathrm{T}$ " harfinin sırasını beklerken konuşmalarını hazırlamışlardır. Konuşmayı Zeki Mesud Bey yapmıştır. Mesud Bey'in konuşması aşağıda verilmiştir (Ali Haydar, 1925).

Nazır efendi, reis efendi, hanımlar ve efendiler

Evvel emirde, Türkiye'yi kongreye davet eden ihzari komite ile Çekoslovak hükümetine takdim-i teşekkürat eylerim. Türkiye birinci defa olarak beynelmilel tedrisat kongresine iştirak etmektedir. Fakat bu Türkiye'nin bundan evvelki kongreler mesaisine lakayt kaldığı manasına tazammun (içerme) etmez. Sizlerce de pek âlâ malumdur ki biz Türkler senelerden beri mevcudiyet ve istiklalimizi muhafaza için mücadele de bulunuyorduk. Bütün maddi ve manevi kuvvetlerimiz ancak bu mücadelede muzaffer çıkmak cehd-ü emeline masruf (harcanmış) idi. Bu gün Türkiye harici ve dâhili düşmanlarından kurtulmuş, serbest, müstakil bir devlettir. Hükümeti en demokratik bir şekl-i idareye maliktir. Halk hükümetlerinin en birinci vazifesi halkı talim ve tenvir (aydınlatma) etmek olduğu için büyük millet meclisi hükümeti de bu noktaya bütün dikkat ve gayreti hasr (tahsis etme) etmiştir. Avrupa ilim ve irfanından istifade için her türlü vesaite müracaat ettiği gibi dâhilen de maarif ve mekatib teşkilatını tensik (düzenlemek) için azami kudretini sarf eylemektedir. Biz Türkler ümit ediyoruz ki bu kongrenin mesaisinden pek çok istifade edeceğiz. Memleketimize yeni ve güzel fikirler nakline muvaffak olacağız. Kongrenin muvaffakiyetini temenni ederek cümlenizi gerek hükümet ve gerek Türkiye muallimleri namına selamlarım.

Yaşasın beynelmilel tedrisat kongresi, yaşasın misafirperver ve serbest Çekoslovakya!

\section{Kongrede Tartışılan Konuların İçeriği}

Kongrede konuların müzakere edilmesine geçilmeden önce bir veya iki kişinin rapor okuması durumu gerçekleşmiştir. Ali Haydar Bey kitabında net bir biçimde bahsetmese de anlaşıldığı kadarıyla kongrede bazı komisyonlar oluşturulmuş ve bunlar rapor hazırlamışlardır. Raporların bir başka şekilde hazırlanması ise ülkelerin toplulukları tarafından gerçekleşmiştir. Ayrıca Ali Haydar'ın verdiği bilgiler 1şığında bazı raporlarında kişilerin kendilerinin hazırladığı yönünde ipucuna rastlanılmıştır (Ali Haydar, 1925).

\section{Ortaöğretim Öğretmenlerinin Eğitimi}

Salı günü (28 Ağustos 1923) öğleden sonra lise öğretmenlerinin eğitimlerinin nasıl olacağı konusunda bir oturum gerçekleştirilmiştir. Oturumda eğitim bilimci Chlup tarafından Fransızca bir rapor okunmuş̧tur. Bu raporda; eğitim biliminin bir bilim olduğunu fakat bu bilimin dinamiklerine uygun davranan öğretmenlerin olmadığı, öğretmenin kendi başına öğretim usullerini keşif edebilecekleri anlayışının var olduğu ve öğretmenlerin çok az bir pedagoji bilgisine sahip olduğu, derslerde yoğun alan bilgisi verildiği yönünde eleştiriler yer almıştır. Ayrıca öğretmenin öğrencilerini tanıyabilmesi için onların psikolojik ve biyolojik, bedeni ve ahlaki gelişimlerini tanıması, lise öğretmenlerinin öğretim yöntemlerinin kaidelerini, işleyeceği dersin kurallarını, okul sistemini bilmelerinin önemi üzerinde durulmuştur. Mevcut durumda öğretmen adaylarına verilen eğitim yeterli görülmemiştir. Verilen meslek derslerinde eğitimin tarihini bilmenin üzerinde daha çok durulduğu konusunda eleştiri yapılmıştır. Bu nedenle eğitim tarihi dersi yerine eğitim tarihinin felsefesinin okutulması önerilmiştir. Özelliklede öğretmen adaylarına teorik psikoloji, çocuk psikolojisi, öğrenci psikolojisi, bireysel psikoloji, pedagojik yöntemleri uygulamalı olarak gösterilmesi tavsiye edilmiştir. Bundan başka tatbikat mektepleri açılması, ögretmen adaylarının burada deneyim kazanmaları tavsiye edilmiştir. $\mathrm{Bu}$ rapor da özellikle de Çekoslovakya eleştirisi yapılmıştır. Çekoslovakya'da lise öğretmeni yetiştirecek öğretmen okulu olmadığ 1 , öğretmen olmak isteyenlerin üniversitede okuduğu belirtilmiştir. Bu nedenle tatbikat mekteplerinin üniversiteye bağlı olarak açılması önerilmiştir (Ali Haydar, 1925). 
Profesör Chlup'tan sonra Prag'daki Comenius Terbiye Darülmesaisi azasından olan mösyö Vanura raporunu okumuştur. Ona göre öğretmenin başarısının altında aşk ve ilim vardır. $\mathrm{O}$, öğretmenlerin geçimini sağlamak için görev yapanlarının değil de mesleğe yeteneği olup öğretmenlik yapanların başarılı olabileceğine inanmıştır. Öğretmenin öğrencisine sadece bilgi vermesini yeterli görmemiş onların eğitimleri ile de ilgilenmesini uygun görmüştür. $\mathrm{Bu}$ nedenle öğretmenlerin pedagoji öğrenmeleri gerekliliği üzerinde durmuştur. Öğrencinin pedagojik bilgiyi teorik olarak üniversitede görürken staj da yapması gerekliliğine değinmiştir. Vanura bu konuda hâkim olan iki farklı düşünceyi de dile getirmiştir. Düşüncelerden biri öğrencinin önce alan derslerini daha sonra da pedagoji derslerini alması, bir diğeri ise alan ve pedagoji derslerinin aynı anda alınmasıdır. Vanura ise bu iki görüşten ikincisini savunmuştur. $\mathrm{O}$, meslek derslerinin alan bilgisini aldıktan sonra verilmesinin öğrencideki fikri ve ahlaki etkilerini azaltacağını, fazladan yıl okuma durumuna düşürüleceğini belirtmiştir. Ayrıca derslerini bitiren öğrencinin kendi alanındaki bir öğretmenin yanında staj yapmasını, stajyer verilen öğretmene bir ücret verilmesini, mektep müdürlerinin de stajyere okul idaresi konusunda bilgi vermesini, onları idari işlere alıştırmasını tavsiye etmiştir. Staj müddetinin bir yıl devam etmesi ve öğrenci başaramaz ise altı ay daha uzatılmasını belirterek staj sonunda öğrencinin eğitim bilim, eğitim tarihi ve öğretim yöntemleri konularında bir sınava tabi tutulmasını gerekli görmüştür (Ali Haydar, 1925).

Yukarıdaki raporlardan sonra tartışmalara geçilmiştir. Toplantıda Bulgaristan, Çekoslovakya, İtalya, Fransa adına konuşanlar olmuştur. Genelde staj devresi, öğrencilerin pedagoji eğitimlerini almaları ve öğretmenlerin bilgiyi hazır bir tarzda vermemeleri konuları katılımcılar tarafından desteklenmiştir. Fakat bu konulara itirazı olanlar da çıkmıştır. Fransa temsilcilerinden Fedel öğrencilerin pedagoji bilgileri için bir eğitim-öğretim süreci yaşamalarını mantıklı görmemiş, bütün pedagojik kaideleri birkaç dakika zarfında öğrenilebilecek birkaç reçeteden ibaret olarak görmüştür. Yani bu toplantıda iki görüş ortaya çıkmıştır. Üniversitede alan derslerini gören öğrencilerin buralarda pedagoji eğitimlerini de almasını doğru olduğunu düşünenler bir görüşü oluşturmuş, sadece alan bilgisinin verilmesini yeterli görenler bir diğer görüşü temsil etmişlerdir (Ali Haydar, 1925).

Oturumda ise alınan kararlar şunlardır; her öğretmenin kendi alanı ile ilgili derin uzmanlık alması ve genel kültür bilgisine sahip olması kanaatine varılmıştır. Kongre her milletin kendi kültürü ve ihtiyacına göre öğretmen yetiştirmesinin taraftarıdır. Öğrencinin eğitimini felsefi ve tarihi usullerle ve uygulamalarla birleştirdiği takdirde eğitim ve öğretim yeteneğinin gelişeceği yönünde bir kanaat de ortaya çıkmıştır. Ayrıca staj yaparken belirli bir ücret verilmesini tavsiye etmişlerdir (Ali Haydar, 1925).

Toplantıya Türkiye'den katılım gerçekleştirilmesi, ülkenin dış dünyadaki gelişmelere kayıtsız kalmadığının göstergesi olarak yorumlanabilir (BCA, FK.30.18.1.1.-YN.7.16.15; FK.30.18.1.1.YN.9.25.20; Ali Haydar, 1925). Ayrıca toplantının olduğu günlerin hemen öncesinde I. Heyet-i İlmiye'de gerçekleştirilmiştir (Tanır \& Aslan, 2019). Bu durum Türkiye'de eğitim konusunda yeni arayışların olduğunu hissettirmiştir. Fakat şunu da belirtmek gerekir ki Çekoslovak yetkililerinin yapılmasını tavsiye ettikleri konularda Osmanlı döneminden beri çeşitli çalışmalar yapılmıştır. Onların istediği öğretmenlik uygulaması yapılması, Osmanlı'dan itibaren sürdürülmüştür. Vanura'nın staj sonunda yapılmasını tavsiye ettiği pedagoji dersleri sınavı Türkiye'de staj döneminden sonra uygulanan bir durumdu. Hatta Türkiye daha 1913-1914'de bir staj yönergesine sahiptir. Lise öğretmeni yetiştirilmesi içinde Darülmualliminde bir Âlî şube vardır. Yalnız Âlî şubenin varlığı konusunda hem Osmanlı döneminde hem de Cumhuriyet döneminde çeşitli tartışmalar olduğunu da göz ardı etmemek gerekir. Nitekim bu tartışmalar bu şubenin öğrencilerinin alan derslerini üniversitede, meslek derslerini de kendi okullarında görmeleri neticesinde ortaya çıkmıştır. Osmanlı'dan Cumhuriyet'e bu konu tartışılmıştır. Bazı Osmanlı ve Cumhuriyet dönemi eğitimcileri alan derslerinin üniversitede alınmasını doğru bulmamış, öğretmenin öğretmen okulunda yetişmesi inancını taşımışlardır. $\mathrm{Bu}$ eğitimciler içerisinde Satı Bey gibi önemli bir isimde vardır (Ferid, 1325a; 1325b; Sat1, 1327; İbrahim Alaaddin, 1923; Sadreddin Celal, 1924; Süleyman Şevket; 1924, Becerikli, 2019a). Kısaca durum şu şekilde özetlenebilir; eğitim-öğretim işinin bir süreç olduğu ve ülkelerin bu konularda nasıl daha iyi olunacağı konusunda çalışmalar yaptığı, hatta bu paylaşımların uluslararası olarak yapılması için kongreler düzenlendiğidir.

\section{Okul ve Aile}


Bu oturum 30 Ağustos 1923 perşembe günü gerçekleştirilmiştir. Belçika'nın Gent şehrindeki ortaokul öğretmenlerinden R. Van Damme tarafindan okul ve aile ilişkilerine ait bir rapor okunmuştur. Raporda okul ile aile arasında sıkı bir bağ olması gerekliliğinin üzerinde durulmuş ve böyle bir bağın kurulmasının eğitim-öğretime ciddi bir katkı sağlayacağı belirtilmiştir. 1917'de bu amaçla Belçika'da "Orta Tedrisat Muhibleri İttifakı/Ligue des Amis de I'enseignement Moyen Officiel" kurduklarından bahsetmiştir. Bu ittifakın amacı Gent şehrinde bulunan ortaokulların olgunlaşmasına hizmet etmek, maddi ve eğitim-öğretim açısından okullara yardım etmektir. Bu nedenle fayda sağlamak için eğlence, konferans, kurslar ve geziler, piyango ve sair şeyleri yapmışlardır (Ali Haydar, 1925).

Oturumda Prag Real mektebi müdürü mösyö Pithardt bir rapor okumuştur. Raporda Çeklerin aile ve okul arasında ilişkiyi kurmak için ne gibi faaliyetler düzenlediklerini bildirmiştir. Eğitim bakanlıkları tarafından bir anket düzenlendiğini, bu anketin neticesinde velilerin isteği doğrultusunda ders programları ve sınavları hafifletmiş olduklarını ifade etmiştir. Fakat Dünya Savaşı'nın etkileriyle bu ilişki güçlendirilememiş, aile bireylerinin askere gitmesi ve geçim derdi olmasının bu işi zora soktuğundan bahsedilmiştir. Savaştan sonrada aile ve okul arasında bağ kurma işinin başarılı olmadığ da özellikle belirtilmiştir. Aile ve okul arasında bağ sağlanamamasının sebepleri ise bencilliğe, gurura, ailelerin lakayt davranmasına, çocukların durumunu öğretmenlerine bildirmekten çekinmelerine dayandırılmıştır. Ailelerin çocukları hakkında zekâ, ahlak ve huyları konusunda bilgi verilmesinin iki unsur arasında yakınlaşmayı sağlamasına yarar göstereceğine inanılmıştır. Ayrıca bu bağ için ebeveynlerin okula gelmesini beklemektense okulun aileye gitmesi tavsiye edilmiştir. Bunun bazı bölgelerde yapılabildiği ve öğretmenler ile velilerin toplantı yaptıkları belirtilmiştir. Ayrıca farklı ülkelerin deneyimlerinden de yararlanmak istediklerinin altı çizilmiştir (Ali Haydar, 1925).

Müzakerelere geçildiğinde Yugoslavya temsilcisi kendi ülkelerinde öğrenciler ve velilerden oluşan bir teşkilat kurduklarını ve bu teşkilat aracılığıyla öğrenci ile ailelere kitap, spor aleti tedarik ettiklerini belirtmiştir. Ayrıca bir sonraki sene okullarda uygulanan öğretim yöntemleri ile ilgili çeşitli konferanslar vererek okullar arasındaki yöntem uygulamalarında bütünlük sağlamak istediklerini belirtmiştir. Bunun dışında İsveç temsilcisi velilerin öğretmenin azil ve atamalarında etkili olup olmayacağı sorusunu yöneltmiş fakat bu konu üzerinde fazla durulmadan toplantının ortak kararları alınmıştır. Alınan kararlar; aile ve okulun bağlarının güçlendirilmesi uygun görülmüş ve desteklenmiş fakat ailelerin öğretmenlerin atama ve azillerine müdahalesi uygun bulunmamıştır (Ali Haydar, 1925).

\section{Ortaöğretimde Ahlak Eğitimi}

Günümüz Türkiye'sinde değerler eğitimi diye adlandırılan bireylerin karakter oluşturma süreci, geçmişte ahlak eğitimi diye kavramlaştırılmıştır. Ahlak eğitimini sadece Türkiye'de gelişim göstermemiş çeşitli ülkelerde de üzerinde durulan bir önemi olmuştur (Yıldırım, 2019). Keza Prag kongresinde de ahlak eğitimine yer ayrılmış olması konunun Avrupa ülkeleri açısından ciddiyetle ele alınıp üzerinde düşünüldüğünün göstergesi olarak değerlendirilebilir.

Kongre'de ahlak eğitimi ile ilgili tartışmalara geçilmeden önce ilk konuşmayı Profesör Klima (Prag'da Real mektebi öğretmenlerinden) yaparak ahlak eğitimi ile ilgili bir rapor okumuştur (29 Ağustos 1923). Okunan raporda okullardaki bütün faaliyetlerin bir ahlaki amaca hizmet etmesi üzerinde durulmuştur. Dünya savaşının sadece maddi sorunlara yol açmadığını, ahlaki çöküntülere de neden olduğu belirtilmiş, bütün toplumun gözlerini siyasi, mali ve ticari amaçlara doğrulttuğu ifade edilmiştir. Bu nedenle gençlere vatan, özgürlük, insanlık için kendini feda etmek gibi erdemlerin öğretilmesi gerekliliği vurgulanmıştır. Ayrıca çeşitli örneklerle eğitimcinin vazifesinin, öğrencilere, kendilerine ve topluma karşı ahlaki olarak güçlü bir irade kazandırmasının da olduğu vurgulanmıştır. Hatta ahlak eğitiminde en önemli unsurunun öğretmenin kendi tavırları, hal ve hareketi olduğu belirtilmiştir. Ayrıca okullarda sistematik bir ahlak dersi olmasının önemi üzerinde durularak bunun da gerekçeleri; ders programlarının çok ağır olduğundan öğretmenlerin öğrencileri ile ahlak sohbetleri yapmasının fırsatının olmadığı ve eğitim sayesinde öğrencinin ahlaki gelişiminin daha iyi sağlanacağı şeklinde oluşturulmuştur. Ahlak eğitiminin vatandaşlık eğitimiyle pekiştirilmesi gerekliliği üzerinde de durmuştur. Ayrıca ilk ahlak eğitiminin ailede verildiğini, erdem tohumlarının burada atıldığını bu nedenle çocuklar yüksek gayeler için toplumun kurallarına itaat etmeye alıştırılırsa gelecekte iyi vatandaş olacakları kanaati öne sürülmüştür. Yapılacak ahlak dersinin sayesinde öğrencilerin kazanacağı ahlaki faziletlerin bireyin iç dünyası ve insanlığın yararına hizmetinin önemini 
anlayacakları ileri sürülmüştür. Raporda diğer bütün derslerin de içerisinde ahlaki ögelerin olması tavsiye edilmiştir (Ali Haydar, 1925).

Ahlak eğitimi üzerine Türkiye'de de önem gösterildiği hatta Osmanlı'dan itibaren okulların programlarına müstakil bir ahlak dersi konulduğunu söylemek mümkündür. Osmanlı eğitimcileri ahlak konusunda çeşitli eserler vermişler, ahlak öğretiminin nasıl gerçekleşeceği yönünde yöntem makaleleri yazmışlardır. Osmanlı' da ahlaki öğretilerde din etkisi varken Cumhuriyet ile birlikte daha laik söylemler geliştirilmiştir. Ayrıca ahlak ve vatandaşlık birbirinin neden ve sonucu olarak ilişkilendirilmiştir. Özellikle öğretmenin rol model olması, ahlakın hikâye ve şiirlerle telkin yoluyla verilmesi anlayışı toplantıda konuşulanlar ile Türkiye'nin eğitim hafızasının ahlak eğitimi yönünde birbirine benzediğini açığa çıkarmaktadır (Becerikli \& Yıldırım, 2018; 2020). Şunu da belirtmek gerekir ki Türklerin İslamiyet'i kabulünden önce ve sonra uzun tarihsel sürecinde ahlak anlayışında ciddi farklılıklar olmamış, vatansever olma, adil olma, sabırlı olma, kanaatkâr olma, yardımsever olma gibi temel özellikler korunmaya çalışılmıştır (Yıldırım, 2019).

Ahlak oturumunda sunulan bir diğer raporu Fransa yatılı lisesi öğretmenlerinden mösyö Faviers okumuştur. $\mathrm{Bu}$ raporda; ortaöğretim kurumlarının meşru ve asil bir davasının namuslu insanlar yetiştirmek olduğu söylenmiştir. Bu nedenle verilecek eğitimle ahlaki eksikliği olan âlimlerin yetişmesinin önüne geçilmesi gerekliliği ifade edilmiştir. Faviers'in okuduğu rapor Fransa'daki laik eğitimin sancıları hakkında da bilgi edinilmesi yönünde ipuçlarını vermiştir. Raporda; ahlaki eğitimin dinden ayrı bir yere konulmasından, ondan bağımsız olmasından bahsedilmiştir. Bunu sağlamak için ise Fransa'da 1850 ile 1880 arasında çok mücadele olduğu fakat bu davanın kazanıldığı ifade edilerek ahlakın dini ibadetlere karşı üstün geldiği belirtilmiştir. Görünen o ki Fransa'da ahlak ile din ayrımı yapılmaya çalışılmış, Ahlaki öğretilerin din temelli olmaktan çıkarılması adına mücadeleler gerçekleşmiştir. Başka bir Fransız temsilci mösyö Cope devlete ait laik öğretim kurumları için Fransa' da "Allahsız Mektep/Ecole sans Dieu" diye bahsedildiğini vurgulamıştır. Yine o da raporda geçtiği gibi benzeri konulara değinerek dinin mektebin eşiğinde durması yönünde ifadelerde bulunmuştur (Ali Haydar, 1925).

Matmazel Rosova (Ukrayna Mültecileri Temsilcisi) ise sistematik bir ahlak dersinin okutulmasını pek doğru bulmamış, çocuklarda topluma karşı ilgi alaka uyandırılmasının yeterli olacağını belirtmiştir. Ahlakın sözle anlatılamayacağını bunun gençlere ancak şiir, edebiyat, güzel sanatlar sayesinde verilebileceğini iddia etmiştir (Ali Haydar, 1925).

Rojiçka (Çekoslovakya) teorik ahlak ile uygulamalı ahlakın birbirinden ayırılmasının gerekliliğini vurgulamıştır. Orta öğretimde ahlak dersinin olmasını uygun görmüş, ya da felsefe veya tarih dersleri içerisine dâhil edilmesini önermiştir. Ayrıca öğrencilere belirli ahlaki fikirlerin empozesinin demokratik devletlere uygun düşmediğini ifade ederek ahlak hissinin kazandırılmasının zorla değil şiir, güzel sanatlar, tarih ve edebiyat derslerinden faydalanarak telkinler vasitasiyla verilmesi gerektiğinin üzerinde durmuştur (Ali Haydar, 1925).

Oturumda konuşan diğer üyeler de okulların amacının ahlaklı, girişimci, muhakeme edebilen bireyler yetiştirilmesi ve ahlak dersinin dogmatik bir şekilde, herhangi bir dinin etkisiyle olmaması yönünde ifadelerde bulunmuşlardır. Ayrıca öğretmenin öğrenci üzerinde ahlaki etkisinin olması önemli görülmüştür. Toplantının sonunda ise şu karara varılmıştır: Ahlak eğitimi verilirken bireyin vicdan ve fikir özgürlüğüne riayet edilmesi, ahlak dersi verirken çocukta eleştirel düşünme becerilerinin geliştirilmesi, üst sınıflardaki öğrencilere felsefe dersi verilmesi ve burada ahlak fikirleri ile ilgili eleştirel bir bakış kazandırılması kararlaştırılmıştır (Ali Haydar, 1925).

\section{Kızların Eğitimi}

Kızların eğitiminin görüşüldüğü oturumda Matmazel Rosova Çekoslovakya'daki kız okulları hakkında bilgi vermiştir. İlk, kız orta mekteplerinin 1860'da, liselerinin ise daha sonra açıldığı bilgisini vererek kız okullarının erkek orta mektepleri eğitiminden geri olduğunu belirtmiştir (Ali Haydar, 1925). Çekoslovakya bağımsızlığından sonra kız ve erkek okullarının arasındaki ayrımı kaldırmaya yönelik çalışmalar gerçekleştirmiştir. Matmazel Rosova'nın toplantıda verdiği bilgilere göre 1918 senesinden beri çeşitli eğitim yöntemleri uygulanmış ve erkek okullarına kızlar da kabul edilmeye başlanmıştır. 1922-1923 eğitim-öğretim döneminde erkek okullarına devam eden kızların sayısı 16 bin iken kız mekteplerinde okuyanlar 10 bin idi. Ayrıca eğitim görmüş bir kadın, toplumun kültürü için 
bilhassa ailenin ahlak seviyesini yükseltmesi için önemli ad edilmiştir. Fakat aile ve toplumdaki ahlaki rollerinin dışında kadınların beledi ve vatani işlerde de görev almalarının üzerinde durulmuştur. Çekoslovakya'da 266 tane kadın öğretmen olup, maaş, vazife vesaire haklarda erkeklerle eşit görülmüşlerdir (Ali Haydar, 1925). Matmazel Gagnot (Fransa) kendilerinin de benzer haklar talep ettiklerini söyleyen sözler kullanmıştır. Bir başka katılımcı Miss. Forrest (İngiltere)'da bu görüşe katılmıştır (Ali Haydar, 1925). Yapılan açıklamalarda kızların eğitimi ile ilgili İngiltere ve Fransa'nın Çekoslovakya'dan geride olduğu hatta Türkiye'de orta seviye eğitim için açılmış olan ilk kız mektebinin 1858 'de açıldığ dolayı bu konuda ciddi bir birikiminin olduğunu söylemek doğru olacaktır (Demirel, 2002). Bunun yanı sıra kızların eğitimi için 1870'de bir de öğretmen okulunun açılmış olduğunu da göz ardı etmemek gerekmektedir (Erdem, 2013).

Matmazel Valborg Otter (Norveç) oturumda Norveç’te kızların eğitimi ile ilgili bilgiler vermiştir. Otter, kendilerinde 30 seneden beri kadınların orta ve yüksek okullarda eğitim aldıklarını, bu konuda tecrübeye sahip olduklarını belirtmiştir. Norveç'te erkek ve kız okullarının eğitim seviyelerinin aynı olduğu, kız ve erkeklerin de beraber okuyabildiğini, karma tahsil usulüne de öğretmenlerin alıştığını, karma okullarda kız ve erkeklerin zekâ olarak birbirlerinden farkları olmadıklarını, karma okulların en büyük faydasının kız ve erkek çocukları arkadaş gibi yaşamaya alıştırdığını ifade etmiştir. Otter, Norveç'te kız ve erkeklerin ilişkileri genelde iyi olmakla birlikte çok nadir şikâyetler geldiği, teneffüslerde kızların kızlarla, erkelerin de erkekler ile oynadığı, ortaokullarda ise topluluklar oluşturduklarını, flörtlerin olduğunu vurgulamıştır. Otter, kız ve erkelerin beraber okumalarının kızlarda kimseye muhtaç olmadıkları duygusunu geliştirdiğini, erkelerin ise haşinliklerinin azaldığını, iki cinsin birbirinden faydalandığının görüldüğünü ifade etmiştir. Özellikle de her sınıfta birkaç kız olmasının lazım olduğunu belirtmiştir. Fakat bazı derslerde kızlar ve erkeklerin ayrılması gerekliliğini de öne sürmüştür. Nitekim tarih dersini kızların görmemesini uygun görmüş, siyasete kızların ilgisinin olmadığını belirtmiştir. Beden eğitimi ve el işleri derslerinde de erkek ve kızların ayrılmaları gerekliliği üzerinde durmuştur. (Ali Haydar, 1925).

Türkiye'de Osmanlı döneminde sıbyan mekteplerine kız ve erkek çocuklar birlikte okuyabiliyorlardı (Akyüz, 2013). Fakat üst kademelerde karma eğitimin başlaması daha geç tarihlidir. İkinci Meşrutiyet'in ilanı öncesinde kız çocukların rüşdiye (ortaokul) seviyesinde 12 yaşına kadar erkeklerle beraber okumalarına izin verilmiş, ileriki yaşlarda karma eğitime müsaade edilmemiştir (Nurdoğan, 2005). 1920'li y1llara kadar daha üst kademelerde karma eğitim gerçekleşmemiş 1920'lerden itibaren, özellikle de Cumhuriyet döneminde kız ve erkekler beraber okumaya başlamıştır (Kamer, 2013; 2020).

\section{Sonuç}

Prag Uluslararası Öğretmenler Kongresi’nin sonuçları genel bir değerlendirmeye tabi tutulduğunda kongrede üç ana başlıkta incelenen konular hakkında genel geçer sonuçlara ulaşılamadığı hatta tartışma başlığı altında incelenen bazı konuların bir önceki Lüksemburg kongresinde alınan kararların tekrarı ötesine geçemediği görülmüştür.

Özellikle öğretmen yetiştirme sürecinde staj, derslerin dağılımı, derslerdeki genel kültür ve pedagoji ayrımı hususu tartışılmıştır. Bu ve benzer tartışmaların bugün dahi öğretmen yetiştirme program süreçlerinde tartışılıyor olması sorunun henüz tamamen çözüme ulaştırılamamasının açık bir göstergesidir.

Kongrede okul-aile işbirliği üzerinde de durulmuş, bu hususta çeşitli örneklemelerin üzerine gidilmiş ve aileyi eğitimin bir parçası haline getirme fikri ortaya atılmıştır. Günümüzde modern eğitim anlayışında da bu husus oldukça önem arz etmektedir.

Kongrede dikkat çeken önemli bir tartışma konusu da ahlak eğitimi sorunsalı olmuştur. Ahlak eğitimini günümüzle bağdaşması açsından değerler eğitimi ekseninde düşünmek mümkündür. Kongredeki tartışmanın ana çerçevesini savaşlardan yorgun ve bitap düşmüş ve Avrupa'da savaşların bireylerde sebep olduğu ahlaki çöküntü oluşturmuştur. Özellikle savaşların sebep olduğu manevi yoksunluk ve bencillik ahlak eğitiminin okullarda vatandaşlık eğitimiyle beraber götürülmesi fikir birliğine yol açmış, bu hususta da aileler de göreve çağrılarak ilk eğitimin ailede verilmesi gerekliliğinin altı çizilmiştir. Ayrıca din eğitimi ve ahlak eğitiminin de ayrı ayrı değerlendirilmesi gerekliliği üzerinde durulmuştur. Bugün dahi bu durum üzerinde fikir birliğine ulaşamamış bir paradoks olarak karşımıza çıkmaktadır. Ancak şunu da belirtmek gerekir ki yeni kurulacak Türkiye 
Cumhuriyeti kuruluşunun üstünden henüz bir yıl bile geçmeden eğitimde laikliği sağlayacak düzenlemeleri gerçekleştirmeye başlamıştır.

Kongrede günümüzde özellikle geri kalmış ülkelerde var olan bir sorun olan kızların eğitimi hususu da tartışılmıştır. Bu durum pedagojik temelde düşünüldüğünde ülkeler için bir kalkınma ve geri kalmışlık problemi olarak geçerliliğini sürdürmektedir. Kongrede bu sorun ele alınırken başta Avrupa ülkelerinde savaşlardan dolayı kızların eğitime ara verdiklerini ve okul dışında vatan hizmeti yaptıklarının üzerinde durulmuştur. Ancak o yıllarda Avrupa ülkelerinin çoğunda da kız eğitiminin istenilen seviyede olamaması ve eğitimdeki cinsiyet ayrımcıllğı sorunu kongrede tartışma konusu olmuştur. Osmanlı devletinin Avrupa' daki çağdaşlarından çok önce bu hususa önem verdiği ve gerekli adımları attı̆ğ görülmektedir. Ayrıca kongreden henüz birkaç gün önce Ankara'da toplanan Heyet-i İlmiye toplantısında bu hususun Türkiye'de de görüşülmüş olması TBMM Hükümetinin konuya verdiği ehemmiyeti göstermektedir.

Prag Uluslararası Öğretmenler Kongresi’nin toplanması öğretmenlik mesleğinin ve eğitim sorunlarının uluslararası bir toplantıda ele alınması açısından oldukça önemlidir. Burada oldukça önem atfedilebilecek bir gelişme de Ankara'da Milli Mücadele'den henüz çıkmış TBMM Hükümeti'nin kongreye davet edilmesi ve o dönemki adıyla Maarif Vekâletinin bu kongreye temsilci göndermesidir. Bu durum yeni Cumhuriyetin öğretmenlik mesleği ve eğitimle ilgili uluslararası bir toplantıya verdiği önem ve yeni bağımsız siyasal rejimin bu tip organizasyonlarda temsil arzusuna verdiği ehemmiyetle açıklanabilir. Kongre sürecinde Zeki Bey'in konuşması bu heves ve ehemmiyeti açıkça göstermektedir. Özellikle Ali Haydar (Taner) Bey'in yolluklu yevmiyeli görevlendirilmesi ve kongre bitişinde şehirdeki eğitim kurumları hakkında da kendisinden gözlemlerinin istenmesi Türkiye'nin dünyadaki gelişmeleri takip etme isteğini göstermesi açısından oldukça dikkat çekicidir. Ali Haydar Bey, Almanya'da Jane Üniversitesinde eğitim ve psikoloji tahsili yapmış, 1911 yılında Selanik'te İttihad ve Terakki kontrolündeki bir okulda pedagoji hocalı̆̆1 yapmıştır (Ata, 2017). Aynı tarihte Selanik’te düzenlenen Öğretmenler Kongresine katılmış, İttihad ve Terakki mektebini temsil etmiştir (Selanik Vilayeti Birinci Muallimler Kongresi Mecmuas1, 1328). Ali Haydar bu kongrenin ikinci toplantısında öğretim yöntemleriyle ilgili bir konferans vermiştir (Becerikli, 2019b). 1915'te Maarif Nezareti Müşavirliğine atanan Alman Müşavir Dr. Franz Schmidt'in tercümanlığını yapmış ve Darülfünunda Tecrübi Pedagoji ve Tecrübi Psikoloji gibi dersleri vermiştir. 1926'da başladığ Talim ve Terbiye Kurulu üyeliğini 12 yıl sürdürmüştür. "Milli Terbiye" adlı raporu, çağdaş eğitimden beklentileri de yansıttığından dönemi için önemlidir. 1927'de Hilmi Kitapevi'nden Kur'an-1 Kerim Elifbası adlı alfabe kitabı çıkmıştır. Milli Eğitim Bakanı Mustafa Necati döneminde Grigori Petrof'un Beyaz Zambaklar Memleketinde kitabının çevirmeni olarak şöhret kazanmıştır (Ata, 2017). Ali Haydar Bey'in bu çok yönlü münevver kişiliğinin kongrede görevlendirilmesinde etkisinin olup olmadığı yönünde net bir kanıt elde edilememiştir yalnız kendisini uzman bir pedagog olarak tanımlamak yanlış olmayacaktır.

\section{Kaynakça}

Akyüz, Y. (2013). Türk eğitim tarihi (m.ö. 1000-m.s. 2013). Ankara: Pegem Akademi. Ali Haydar (1923a). Çekoslovakya intibaları. Muallimler Mecmuası, 2(13), 272-281.

Ali Haydar. (1923b). Çekoslovakya intibaları. Muallimler Mecmuası, 2(14), 293-300.

Ali Haydar. (1924a). Orta mekteplerin beynelmilel Prag kongresi. Muallimler Mecmuast, 3(25), $917-$ 945.

Ali Haydar. (1924b). Prag kongresi. Muallimler Mecmuast, 3(26), 997-1030.

Ali Haydar. (1925). Orta mekteb muallimleri Prag kongresi. İstanbul: Matbaa-i Amire.

Ata, B. (2017). Türkiye'de bir psikolog tarih ders kitabı yazarı oldu: psikolog Ali Haydar Taner ve ortaokul için tarih II üzerine. Turkish History Education Journal, 6(2), 215-242.

Azarkan, E. (2013). II. Dünya Savaşı öncesi dönemde devletlerin tanınmasında etkili olan faktörler. Dicle Üniversitesi Hukuk Fakültesi Dergisi, 17-18(26-27-28-29), 1-24.

BCA, FK.30.18.1.1.-YN.7.16.15.

BCA, FK.30.18.1.1.-YN.9.25.20.

BCA, FK.HR.IM.-YN.77.37.1.

Becerikli, S., \& Y1ldırım, S. G. (2018). The moral and citizenship education methods performed in the last period of Ottoman. Educational Research and Reviews, 13(16), 609-616. 
Becerikli, S., \& Yıldırım, S. G. (2020). Evaluation of citizenship education and values education in the early years of the republic. International Journal of Evaluation and Research in Education (IJERE), 9(1), 45-53.

Becerikli, S. (2019a). Öğretmen yetiştirmede İstanbul yüksek öğretmen okulu modeli (1924-1978). (Yayımlanmamış doktora tezi). Bursa Uludağ Üniversitesi Eğitim Bilimleri Enstitüsü. Bursa.

Becerikli, S. (2019b). Selanik dârülmuallimîni. F. Demirel (Ed.), Osmanlı Modernleşme Sürecinde Selanik Vilayetinde Eğitim içinde, (s. 201-229). İstanbul: İdeal Kültür Yayınları.

Ferid. (1325a). Darülmuallimin-i âliyenin lağvı üzerine maarif nezaretine açık mektup. Darüşşafaka, 6, 281-284.

Ferid. (1325b). Darülmuallimin-i âliyenin lağvı üzerine maarif nezaretine açık mektup. Darüşşafaka, 7, 313-315.

Fraenkel, R. Wallen, N. E., \& Hyun, H. H. (2011). How to design and evaluate research in education. New York: Connect Learn Succeed.

İbrahim Alaaddin. (1923). Darülmuallimin ve darülmuallimat-1 âliye teşkilatı, Muallimler Mecmuası, 1(5), 74-76.

Kamer, S. T. (2013). Türk eğitim sisteminde karma eğitime ilişkin fikirler, tartışmalar ve uygulamalar (1908-1950). (Yayımlanmamış doktora tezi). Ankara Üniversitesi Eğitim Bilimleri Enstitüsü. Ankara.

Kamer, S. T. (2020). Kadın düşünürlerin karma eğitime ilişkin görüşleri. Alpaslan Demir, Tuba Tombuloğlu, Oğuz Polatel (Ed.), Türklerde Kadın içinde, (s. 303-322). Konya: Kömen Yayınları.

Nurdoğan, A. M. (2005). Osmanlı modernleşme sürecinde ilköğretim (1869 - 1922). (Yayımlanmış doktora tezi). Marmara Üniversitesi Türkiyat Araştırmaları Enstitüsü. İstanbul.

Oruç, Ş., \& Kırpık, G. (2006). Osmanlı'da modern öğretim, strateji, yöntem ve teknikleri. Ankara: Gazi Kitapevi.

Sadreddin Celal. (1924). Darülmuallimin meselesi. Muallimler Mecmuası, 2(19), 460-462.

Sat1. (1327). Darülmualliminin bir senelik hayatı, Tedrisat-ı Ibtidaiye Mecmuası, Nazariyat ve Malumat Kismi, 2(15), 81-85.

Selanik vilayeti birinci muallimler kongresi mecmuası. (1328). Selanik: Osmanlı Matbaas1.

Süleyman Şevket. (1924). Orta darülmuallimat ve darülmuallimin. Muallimler Mecmuası, 2(20), 575 587.

Şanal, M. (2002). Türkiye'de öğretmen okullarında meslek dersi kitaplarının pedagojik açıdan değerlendirilmesi (1848-1918). (Yayımlanmamış doktora tezi). Ankara Üniversitesi Eğitim Bilimleri Enstitüsü, Ankara.

Tanır, E. D., \& Aslan, C. (2019). Birinci heyet-i ilmiye ve çalışma esasları. Ankara Üniversitesi Eğitim Bilimleri Dergisi, 52(1), 1251-276.

Yı1dırım, S. G. (2019). Değerler eğitimine yönelik bir model önerisi: değer içselleştirme. (Yayımlanmamış doktora tezi). Bursa Uludağ Üniversitesi Eğitim Bilimleri Enstitüsü, Bursa. 